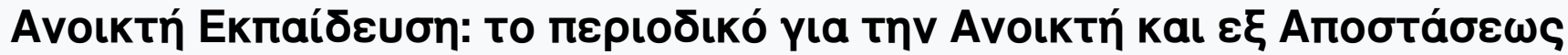

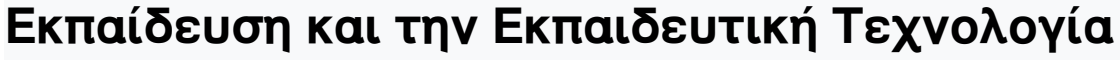

Tóp. 12, Ap. 2 (2016)

Volume 12

Number 2

2016
ISSN $1791-9312$

Social Media in Greek K-12 education: A research model that explores teachers' behavioral intention

Babis Georgakainas, Panagiotis Zaharias

doi: $10.12681 /$ jode.10864

\section{Open}

\section{Education}

The Journal for Open and Distance Education and Educational Technology

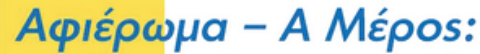

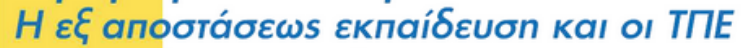

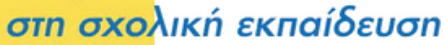

\section{$\sum_{0}^{5}$}

A periodical electronic publication of the Scientific Association: Hellenic Network of Open and Distance Education

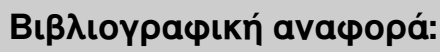




\title{
Social Media in Greek K-12 education: A research model that explores teachers' behavioral intention
}

Babis Georgakainas Aristotle University of Thessaloniki PhD Candidate geobabis@hotmail.com

Panagiotis Zaharias Open University of Cyprus Adjunct Faculty pz@aueb.gr

\begin{abstract}
During the last decade we have witnessed a rapid growth of Web 2.0 technologies and especially the so-called online social media. Many people, from every age group but especially teenagers, participate in online communities, making new friends and exhibiting themselves and their interests in a huge international audience. It is extremely important for educational practitioners and researchers to successfully incorporate the dynamics of web 2.0 and social media in their practices. This is especially true for the teachers of K-12 education. The main aim of this study is to examine the factors that may affect teachers' behavioral intention to use social media in their classes. Very little is known from teachers' perspective and empirical work is very limited, especially from Southern European countries. This research was setup in order to develop and test a seven-factor model to explain the Greek teachers' behavioral intention to use social media in their classes. Findings reveal that Experience, Perceived Usefulness and Trialability have a significant impact while Subjective Norms and Perceived Ease of Use have a more weak impact on teacher's behavioral intention.
\end{abstract}

\section{Keywords}

Social media, digital natives, Education 2.0, teachers' behavioral intention.

\section{Introduction}

Web 2.0 "is not a technological revolution, it is a social revolution" (Downes, 2005). Social networking websites have become an essential part of the daily communication patterns for many individuals. At the same time, the pupils in the schools are members of "Net Generation" or as they are often called "Digital Natives". These terms identify a new generation of individuals who are comfortable (almost in their nature) at using technologies (Rosen \& Nelson, 2008). Education could not remain unaffected by this progress. One of the greater key stakeholders in these changes in schools and especially in the diffusion of an innovation is the teacher. To this end, in this study the main aim is to explore the factors that may affect teachers in Greek schools to adopt and integrate social media in their classes and educational activities. Much work has been done but most of it is still anecdotal and there is a scarcity of relevant research that delineates these factors especially for the Greek elementary and high schools. 


\section{Background literature}

Arising from the interests to understand teacher's intention to use technology and especially social media, the research has turned to several theories with their origins from social psychology. Among these, the Technology Acceptance Model (TAM), the Theory of Planned Behavior (TPB) and the Diffusion of Innovation by Rogers were widely used and validated.

The Technology Acceptance Model (TAM) has been found to explain user's behavior in computing technologies. It specifies the relationship among perceived usefulness, perceived ease of use and behavioral intention to use technology. However, social media are not officially part of an education system, so their usage in classrooms can still be perceived as an innovation. Following this, two factors from the Theory of Diffusion an innovation of Rogers are used in this research: Trialability and Observability. Finally, the Theory of Planned Behavior (TPB) was an extension of the Theory of Reasoned Action (TRA) and in this research the factors which are used are Subjective Norms and Curriculum as possible reasons that affect the behavioral intention of the teachers to use social media in their classrooms.

Perceived Usefulness was found as a critical factor in many studies during the literature review. In the study of Kale and Goh (2012), the teachers were asked about the use of Web 2.0 in their classrooms and they rated the usefulness of these media very high. According to Wood's survey (Wood, 2010) perceived usefulness and relative advantage were key factors regarding the adoption and use of social virtual worlds in some American colleges. Studies with a focus on game-based learning reveal high perceptions on the relative advantage from such applications as being "more motivating and engaging" (Nielsen, 2010; Kebritschi, 2010).

Ease of Use will be positively associated with learning opportunities, according the study of De Grove et al (2012). Another positive factor that was found was experience with using games in the classroom and curriculum relatedness. Kebritchi (2009) argued that teachers should be given the opportunity to experience the technology (i.e. the educational games in their study) before adopting it. The teachers suggested that offering a trial version of the game for a limited amount of time is an appropriate method. In this study the positive relation between trialability and behavioral intention was found.

The analysis of Kale and Goh (2012) showed that the workload and a structured and standardized curriculum seem to be one of the biggest inhibitors for Web 2.0 adoption. The researchers suggest the need for adjusting and restricting standardized curriculum in order to reduce teachers' workload and providing them with time both in and outside their classrooms to prepare and perform Web 2.0 learning activities.

Observability refers to the degree to which the results of an innovation are visible to potential adopters. It is not easy for anyone to observe the results of use because every application and context is different and the students as users are also different. However, in Nielsen's study (2010), it is reported that educational results can be easily measured in games-based learning. In the study of Teo (2011) a strong relationship between subjective norms and perceived usefulness was confirmed. Motaghian et al. (2013) found that subjective norms increased instructors' perceived usefulness of web based learning systems. In other words, if key stakeholders (e.g. students, fellow instructors and school authorities) support the instructors' use of webbased learning systems, instructors will consider such systems as useful.

According to the literature review it is evident that there are many studies which investigate factors that may affect instructors to their intention to use contemporary 
computer technologies in their courses and educational activities. However, there are still few studies for Web 2.0 tools and even fewer for the use of social media in K-12 students. In addition most of the published literature comes from researchers in American or north-western European educational and research establishments. To this end, in order to cover this gap, we decided to explore the factors which affect the behavioral intention of teachers to use social media in K-12 classrooms in Greek schools.

The Table 1 exhibits models that are used in this study and the relationship between constructs.

\begin{tabular}{|c|c|c|c|c|}
\hline Construct & $\begin{array}{l}\text { Operational } \\
\text { Definition }\end{array}$ & TAM & TPB & Rogers' Theory \\
\hline $\begin{array}{l}\text { Perceived Usefulness } \\
\text { (PU) }\end{array}$ & $\begin{array}{l}\text { The degree to which a } \\
\text { teacher believes that } \\
\text { using social media } \\
\text { would enhance his or } \\
\text { her job performance }\end{array}$ & $(\mathrm{PU} \rightarrow \mathrm{BI})$ & & \\
\hline $\begin{array}{l}\text { Perceived } \\
\text { Ease of Use (PEU) }\end{array}$ & $\begin{array}{l}\text { The degree to which a } \\
\text { teacher believes that } \\
\text { using social media } \\
\text { would be free of effort }\end{array}$ & $(\mathrm{PEU} \rightarrow \mathrm{BI})$ & & \\
\hline Trialability (TR) & $\begin{array}{l}\text { The degree to which } \\
\text { the innovation may be } \\
\text { experimented by } \\
\text { adopters on a limited } \\
\text { basis before full actual } \\
\text { use }\end{array}$ & & & $(\mathrm{TR} \rightarrow \mathrm{BI})$ \\
\hline Observability (OBS) & $\begin{array}{l}\text { The degree to which } \\
\text { the results of an } \\
\text { innovation are visible } \\
\text { to potential adopters. }\end{array}$ & & & $(\mathrm{OBS} \rightarrow \mathrm{BI})$ \\
\hline Experience (EXP) & $\begin{array}{l}\text { The degree of skills } \\
\text { that have a teacher in } \\
\text { the use of social media }\end{array}$ & $(\mathrm{EXP} \rightarrow \mathrm{BI})$ & & \\
\hline $\begin{array}{l}\text { Subjective Norms } \\
\text { (SNM) }\end{array}$ & $\begin{array}{l}\text { The extent to which a } \\
\text { teacher perceives that } \\
\text { most people } \\
\text { who are important to } \\
\text { him think he should or } \\
\text { should not use }\end{array}$ & & $(\mathrm{SNM} \rightarrow \mathrm{BI})$ & \\
\hline Curriculum (CUR) & $\begin{array}{l}\text { The role that plays in } \\
\text { the adoption decision } \\
\text { the congruency of } \\
\text { social media with the } \\
\text { curriculum }\end{array}$ & & $(\mathrm{CUR} \rightarrow \mathrm{BI})$ & \\
\hline
\end{tabular}

Table 1. Relationship between constructs and theoretical models

The relationships presented in the table above, are encapsulated in a research model which is presented in the next figure: 


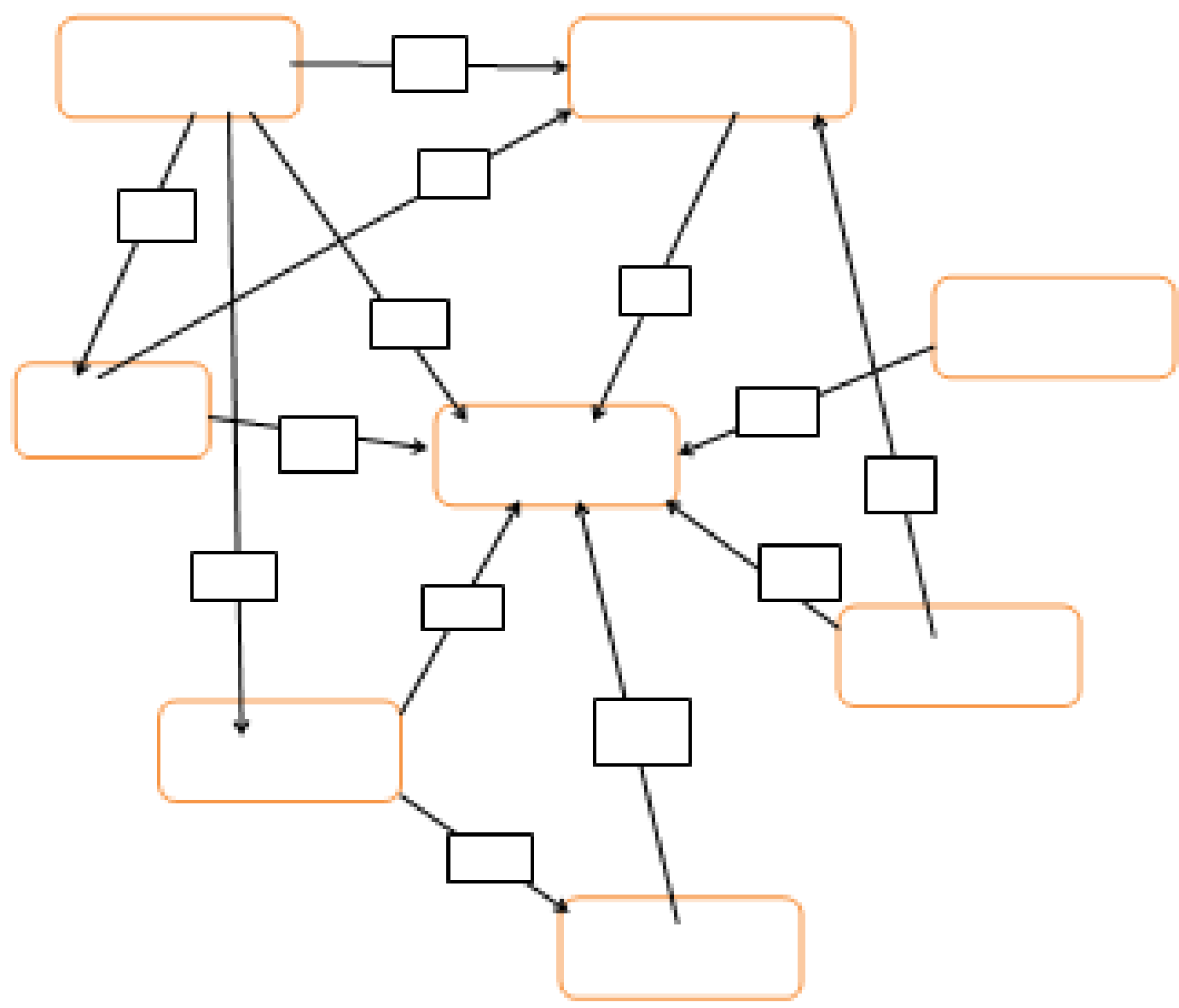

Figure 1. The initial research model

From these relationships the following hypotheses were formulated:

H1: Perceived usefulness will significantly and positively influence teachers' behavioral intention to use social media in their classrooms.

$\mathrm{H} 2$ : Perceived ease of use will significantly and positively influence teachers' perceived usefulness.

H3: Perceived ease of use will significantly and positively influence teachers' behavioral intention to use social media in their classrooms.

H4: Subjective norms will significantly and positively influence teachers' behavioral intention to use social media in their classrooms.

H5: Experience will significantly and positively influence teachers' perceived ease of use.

H6: Experience will significantly and positively influence teachers' perceived usefulness.

H7: Experience will significantly and positively influence teachers' trialability.

H8: Experience will significantly and positively influence teachers' behavioral intention to use social media in their classrooms.

H9: Curriculum will significantly and positively influence teachers' perceived usefulness.

H10: Curriculum will significantly and positively influence teachers' behavioral intention to use social media in their classrooms.

H11: Trialability will significantly and positively influence teachers' observability. 
H12: Trialability will significantly and positively influence teachers' behavioral intention to use social media in their classrooms.

H13: Observability will significantly and positively influence teachers' behavioral intention to use social media in their classrooms.

\section{Method}

\section{Participants and data collection instrument}

In order to examine the research model a questionnaire was used as data gathering instrument in this research. Participants were elementary and secondary school teachers who responded affirmatively to an invitation sent by the researchers through e-mail, social media and personal contact. The questionnaire was delivered with fivepoint Likert scales ranging from strongly disagree (1) to strongly agree (5) and consisted of 51 items which were related to the thirteen constructs of the research model.

In total 206 teachers completed the survey. Table 2 presents the demographic profile of the sample population, where $71.8 \%$ are female and $28.2 \%$ are male. Furthermore $36.9 \%$ of the respondents were between 25-35 years old. The majority of the respondents $(65 \%)$ were secondary schools teachers. $21.1 \%$ of them work in schools for less than 6 years. About half of the respondents (55.9\%) use social media in their classrooms and the vast majority of them (91.3\%) reported that they use YouTube in their personal life.

\begin{tabular}{|c|c|c|}
\hline & Frequency & Percentage \\
\hline $\begin{array}{l}\text { Gender } \\
\text { Female } \\
\text { Male }\end{array}$ & $\begin{array}{l}148 \\
58 \\
\end{array}$ & $\begin{array}{l}71.8 \\
28.2 \\
\end{array}$ \\
\hline $\begin{array}{l}\text { Age (by years) } \\
25 \text { and below } \\
25-35 \\
35-45 \\
45-55 \\
55 \text { and above } \\
\end{array}$ & $\begin{array}{l}4 \\
76 \\
59 \\
59 \\
8 \\
\end{array}$ & $\begin{array}{l}1.9 \\
36.9 \\
28.6 \\
28.6 \\
3.9 \\
\end{array}$ \\
\hline $\begin{array}{l}\text { Type of school } \\
\text { Primary } \\
\text { Secondary }\end{array}$ & $\begin{array}{l}72 \\
134\end{array}$ & $\begin{array}{l}35 \\
65\end{array}$ \\
\hline $\begin{array}{l}\text { Teaching experience (by years) } \\
6 \text { and below } \\
6-10 \\
11-15 \\
16-20 \\
21-25 \\
25 \text { and above }\end{array}$ & $\begin{array}{l}43 \\
54 \\
38 \\
32 \\
18 \\
19\end{array}$ & $\begin{array}{l}21.1 \\
26.5 \\
18.6 \\
15.7 \\
8.8 \\
9.3\end{array}$ \\
\hline $\begin{array}{l}\text { Usage of social media (personal } \\
\text { use) } \\
\text { Facebook } \\
\text { Twitter } \\
\text { Skype } \\
\text { YouTube } \\
\text { Blogs } \\
\text { Wikis } \\
\text { LinkedIn } \\
\text { Other }\end{array}$ & $\begin{array}{l}128 \\
39 \\
135 \\
189 \\
124 \\
81 \\
37 \\
11\end{array}$ & $\begin{array}{l}61.8 \\
18.8 \\
65.2 \\
91.3 \\
59.9 \\
39.1 \\
17.9 \\
5.3\end{array}$ \\
\hline $\begin{array}{llll}\begin{array}{l}\text { Usage of } \\
\text { classrooms }\end{array} & \text { social media } & \text { in } \\
\text { Yes } & & & \\
\text { No } & & & \\
& & & \end{array}$ & $\begin{array}{l}114 \\
90\end{array}$ & $\begin{array}{r}55.9 \\
44.1 \\
\end{array}$ \\
\hline
\end{tabular}

Table 2. Demographic statistics of the respondents 
In order to examine reliability of the questionnaire, the Cronbach's alpha coefficients were calculated. The results showed that the questionnaire was considered highly reliable with $\alpha=0.940$.

\section{Data analysis and results}

From the research model, the constructs between the factors are written in abbreviations which are defined in table 3:

\begin{tabular}{|l|l|}
\hline Constructs & Abbreviations \\
\hline Perceived Usefulness to Behavioral Intention & UFSBHV \\
\hline Ease of Use to Perceived Usefulness & EOUUFS \\
\hline Ease of Use to Behavioral Intention & EOUBHV \\
\hline Subjective Norms to Behavioral Intention & NORBHV \\
\hline Experience to Ease of Use & EXPEOU \\
\hline Experience to Perceived Usefulness & EXPUFS \\
\hline Experience to Trialability & EXPTST \\
\hline Experience to Behavioral Intention & EXPBHV \\
\hline Curriculum to Perceived Usefulness & CURUFS \\
\hline Curriculum to Behavioral Intention & CURBHV \\
\hline Trialability to Observability & TSTOBS \\
\hline Trialability to Behavioral Intention & TSTBHV \\
\hline Observability to Behavioral Intention & OBSBHV \\
\hline
\end{tabular}

Table 3. Constructs and their abbreviations

Table 4 presents descriptive statistics for each of the construct in the research model. The highest mean, equal to 4.18862, belongs to the relationship between Ease of Use and Usefulness (EOUUFS) and it means that most of the instructors agree that the ease of use of social media can reflect their usefulness as educational tools. However, the lowest mean, equal to 3.27683 , belongs to the construct with links Observabilty and Behavioral Intention (OBSBHV) and it means that most of the instructors don't find it important, i.e. to observe the results of the use of social media in order to introduce the in their classrooms.

\begin{tabular}{|l|l|l|}
\hline Construct & Mean & Standard Deviation \\
\hline UFSBHV & 4,09475 & 0,703417 \\
\hline EOUUFS & 4,18862 & 0,722484 \\
\hline EOUBHV & 3,65798 & 0,721665 \\
\hline NORBHV & 3,40625 & 0,737091 \\
\hline EXPEOU & 3,99849 & 0,771432 \\
\hline EXPUFS & 3,94849 & 0,765940 \\
\hline EXPTST & 3,79658 & 0,934995 \\
\hline EXPBHV & 3,84192 & 1,009560 \\
\hline CURUFS & 3,83920 & 0,973178 \\
\hline CURBHV & 3,75254 & 0,492281 \\
\hline TSTOBS & 4,08088 & 0,680238 \\
\hline TSTBHV & 3,82386 & 0,777504 \\
\hline OBSBHV & 3,27683 & 0,889694 \\
\hline
\end{tabular}

Table 4. Descriptive Statistics

Then, a test for normality was conducted using Skewness and Kurtosis. The results are shown in Table 5. It seems that most variables follow a normal distribution except for only three variables (UFSBHV, EOUUFS, EXPBHV) where the distance from the 
boundaries is small so it is accepted that these also follow a normal distribution and there is not a need of transformation.

\begin{tabular}{|l|l|l|l|l|l|l|}
\hline & \multicolumn{2}{l}{ Skewness Interval } & Skewness & \multicolumn{2}{l|}{ Kurtosis Interval } & Kurtosis \\
\hline UFSBHV & $-0,348$ & $+0,348$ & $-1,275$ & $-0,692$ & $+0,692$ & 2,744 \\
\hline EOUUFS & $-0,340$ & $+0,340$ & $-1,2234$ & $-0,676$ & $+0,676$ & 2,044 \\
\hline EOUBHV & $-0,380$ & $+0,380$ & $-0,109$ & $-0,756$ & $+0,756$ & $-0,549$ \\
\hline NORBHV & $-0,366$ & $+0,366$ & $-0,375$ & $-0,728$ & $+0,728$ & 0,350 \\
\hline EXPEOU & $-0,0360$ & $+0,360$ & $-0,641$ & $-0,714$ & $+0,714$ & $-0,169$ \\
\hline EXPUFS & $-0,344$ & $+0,344$ & $-0,862$ & $-0,686$ & $+0,686$ & 1,179 \\
\hline EXPTST & $-0,348$ &,+ 0348 & $-0,570$ & $-0,692$ & $+0,692$ & $-0,269$ \\
\hline EXPBHV & $-0,350$ & $+0,350$ & $-0,854$ & $-0,694$ & $+0,694$ & 0,299 \\
\hline CURUFS & $-0,344$ & $+0,344$ & $-0,775$ & $-0,686$ & $+0,686$ & 0,296 \\
\hline CURBHV & $-0,346$ & $+0,346$ & $-0,184$ & $-0,690$ & $+0,690$ & 0,238 \\
\hline TSTOBS & $-0,372$ & $+0,372$ & $-0,589$ & $-0,740$ & $+0,740$ & 0,650 \\
\hline TSTBHV & $-0,366$ & $+0,366$ & $-0,457$ & $-0,728$ & $+0,728$ & 0,485 \\
\hline OBSBHV & $-0,340$ & $+0,340$ & $-0,194$ & $-0,676$ & $+0,676$ & $-0,111$ \\
\hline
\end{tabular}

Table 5. Normality test

The research model and the hypotheses were examined through analysis of data extracted from the 206 valid responses after performing structural equation modeling (SEM) with the LISREL method. In the literature there are many suggestions about the minimum sample size for the SEM approach. For instance Hair et al. (2006) recommended a sample size between 100 and 400 (Wang \& Wang, 2009) and Newcomb (1992) insisted that no one should use LISREL with fewer than 100 subjects (Park, 2009). Thus, the sample size of this research $(\mathrm{N}=206)$ was adequate for using the SEM technique and LISREL method.

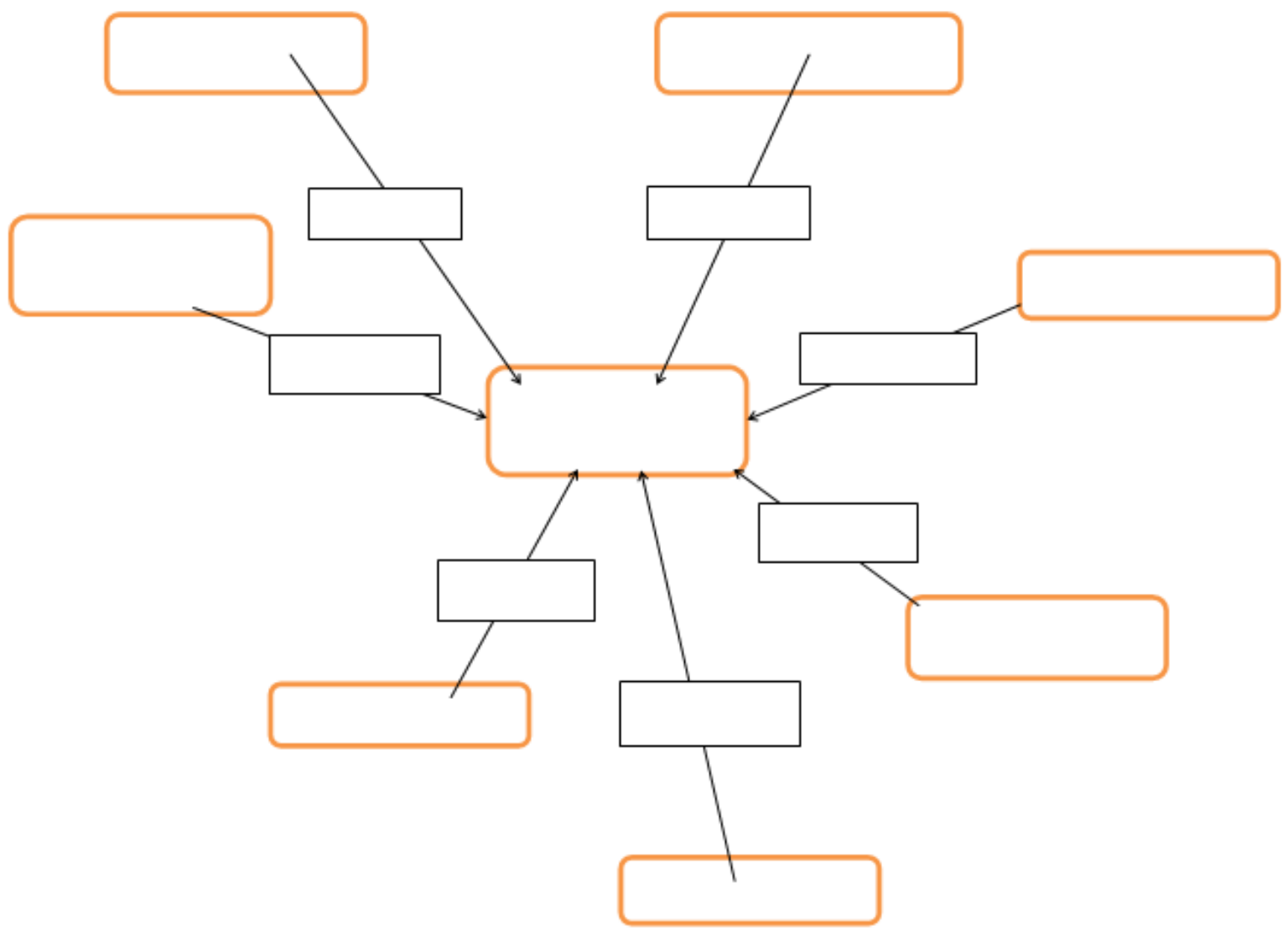

Figure 2.Research Model for SEM analysis 
First of all, ratio LAMBDA-Y was calculated. Values range between 0 and 1 and the closer to 1 the stronger the relationship between the independent variables and the dependent. In the following table the respective variables are exhibited.

\begin{tabular}{|l|l|l|l|l|l|l|l|}
\hline Questions & UFSBHV & EOUBHV & NORBHV & EXPBHV & CURBHV & TSTBHV & OBSBHV \\
\hline Q1a & 0.6567144 & & & & & & \\
\hline Q1b & 0.6816126 & & & & & & \\
\hline Q1c & 0.5698871 & & & & & & \\
\hline Q1d & 0.5434463 & & & & & & \\
\hline Q1e & 0.6072025 & & & & & & \\
\hline Q1f & 0.8154845 & & & & & & \\
\hline Q1g & 0.6658178 & & & & & & \\
\hline Q3a & & 0.40944827 & & & & & \\
\hline Q3b & & 0.18016557 & & & & & \\
\hline Q3c & & 0.87105451 & & & & & \\
\hline Q3d & & 0.93650273 & & & & & \\
\hline Q4a & & & 0.87953032 & & & & \\
\hline Q4b & & & 0.62478205 & & & & \\
\hline Q4c & & & 0.57378590 & & & & \\
\hline Q4d & & & 0.44428570 & & & & \\
\hline Q8a & & & & 0.90224417 & & & \\
\hline Q8b & & & & 0.97123203 & & & \\
\hline Q8c & & & & 0.99974664 & & & \\
\hline Q10a & & & & & 3.94828242 & & \\
\hline Q10b & & & & & 0.01394153 & & \\
\hline Q10c & & & & & 0.01812704 & & \\
\hline Q10d & & & & & -0.105394 & & \\
\hline Q12a & & & & & & 0.72591166 & \\
\hline Q12b & & & & & & 0.82057189 & \\
\hline Q12c & & & & & & 0.73936245 & \\
\hline Q12d & & & & & & 0.56379566 & \\
\hline Q13a & & & & & & & 0.79367903 \\
\hline Q13b & & & & & & & 0.87883159 \\
\hline Q13c & & & & & & & \\
\hline Q13d & & & & & & & \\
\hline
\end{tabular}

Table 6.Lambda-Y ratio for each question

In most variables a significant and balanced contribution of questions was found. However some values indicate some exceptions. The variable EOUBHV (variable Q3b) referred to the relationship between perceived ease of use and behavioral intention has a small contribution. Even in variable CURBHV that relates the Curriculum with the behavioral intention, the trend is formed almost exclusively by the variable Q10a ("The years I teach, I strictly observe the curriculum").

The next indicator is index Gamma, which shows the correlation between the seven latent variables and Behavioral Intention. For index Gamma tool LISREL revealed the following findings:

\begin{tabular}{|l|l|}
\hline Variables & Gamma \\
\hline UFSBHV & 0.78867377 \\
\hline EOUBHV & 0.38246450 \\
\hline NORBHV & 0.45243046 \\
\hline EXPBHV & 0.88136615 \\
\hline CURBHV & 0.03304266 \\
\hline TSTBHV & 0.67885006 \\
\hline OBSBHV & 0.10899899 \\
\hline
\end{tabular}

Table 7.Index Gamma for latent variables 
Gamma values show a strong relationship between Experience, Perceived Usefulness and Testability with the Behavioral Intention of teachers. There is a weak relationship between Ease of Use and Subjective Norms with Behavioral Intention while Observability and Curriculum seems that do not affect teachers in their intention to use social media in their classrooms.

Next table exhibits a correlation matrix between the variables:

\begin{tabular}{|l|l|l|l|l|l|l|l|}
\hline & $\begin{array}{l}\text { UFSBH } \\
\mathrm{V}\end{array}$ & $\begin{array}{l}\text { EOUBH } \\
\mathrm{V}\end{array}$ & $\begin{array}{l}\text { NORBH } \\
\mathrm{V}\end{array}$ & $\begin{array}{l}\text { EXPBH } \\
\mathrm{V}\end{array}$ & $\begin{array}{l}\text { CURBH } \\
\mathrm{V}\end{array}$ & $\begin{array}{l}\text { TSTBH } \\
\mathrm{V}\end{array}$ & $\begin{array}{l}\text { OBSBH } \\
\text { V }\end{array}$ \\
\hline UFSBHV & 1 & & & & & & \\
\hline $\begin{array}{l}\text { EOUBH } \\
\mathrm{V}\end{array}$ & 0.30164 & 1 & & & & & \\
\hline $\begin{array}{l}\text { NORBH } \\
\text { V }\end{array}$ & 0.35682 & 0.173038 & 1 & & & & \\
\hline $\begin{array}{l}\text { EXPBH } \\
\text { V }\end{array}$ & 0.69511 & 0.337091 & 0.398756 & 1 & & & \\
\hline $\begin{array}{l}\text { CURBH } \\
\text { V }\end{array}$ & 0.02606 & 0.012637 & 0.014949 & 0.02912 & 1 & & \\
\hline TSTBHV & 0.53539 & 0.259636 & 0.307132 & 0.59831 & 0.02243 & 1 & 1 \\
\hline $\begin{array}{l}\text { OBSBH } \\
\text { V }\end{array}$ & 0.08596 & 0.041688 & 0.049314 & 0.09606 & 0.0036 & 0.0739 & 1 \\
\hline
\end{tabular}

Table 8.Correlation matrix

There is a strong correlation between Experience and Perceived Usefulness as hypothesis H6 stated. Another hypothesis which is confirmed is H7 between Experience and Testability. There is a weak correlation between Perceived Ease of Use and Perceived Usefulness and between Experience and Perceived Ease of Use. So $\mathrm{H} 2$ and $\mathrm{H} 5$ are weakly confirmed. Finally $\mathrm{H} 9$ and $\mathrm{H} 11$ which refer to the correlation between Curriculum and Perceived Usefulness and between Testability and Observability are not confirmed.

\begin{tabular}{|l|l|}
\hline Constructs & Correlations SEM \\
\hline EOUUSF (H2) & 0.30164 \\
\hline EXPEOU (H5) & 0.337091 \\
\hline EXPUSF (H6) & 0.69511 \\
\hline EXPTST (H7) & 0.59831 \\
\hline CURUSF (H9) & 0.02606 \\
\hline TSTOBS (H1) & 0.0739 \\
\hline
\end{tabular}

Table 9.SEM correlation matrix

In addition, some other values were found from SEM model as follows:

\begin{tabular}{|l|l|}
\hline Chi-Square & 721.26 \\
\hline Df & 398 \\
\hline p-value & 0.00000 \\
\hline RMSEA & 0.063 \\
\hline
\end{tabular}

Table 10.SEM analysis values

In structural equation model (SEM), it is important to examine the "fit" of an estimated model to determine how well models the data. There are different approaches to assessing fit. From the program LISREL, which was used in this SEM analysis, there were calculated some of the more commonly used measures of fit (Table 10). Specifically, the Chi-Squared, which is a function of the sample size and 
the difference between the observed covariance matrix and the model covariance matrix, was calculated to 721.26 while an accepted value is less than 1000 . The pvalue should be less than 0.05 for significance level $95 \%$ and in this case is less than 0.00001. Following the recommendations by $\mathrm{Hu}$ and Bentler (1999), the root mean square error of approximation (RMSEA) and Standardised Root Mean Residual (SRMR) were used as measures of absolute fit and the Comparative Fit Index (CFI) and Tucker-Lewis Index (TLI) as indices of incremental fit. From the literature (e.g., Hair et al., 2010), values of 0.90 or more for the CFI and TLI, and values of 0.08 or less for RMSEA and SRMR are reflective of a good fit. According to the results, the proposed research model has a good fit (RMSEA: 0.063). The results as derived from the SEM model show the model's adjustment in theory, as the indicators in Table 10 are all within the limits of adaptation.

\section{Discussion}

The aim of this research was to develop and test a model to explain the Greek teachers' behavioral intention to use social media in their classes. Seven factors were tested and the results showed that three factors have a significant impact (Experience, Perceived Usefulness, Trialability) while two of them (Subjective Norms, Perceived Ease of Use) have a more weak impact and two of them (observability, curriculum) do not affect teachers' behavioral intention to use social media in their classes.

\section{Experience}

The teachers' experience to new technologies and especially in socially media, affects positively their behavioral intention. Teachers, who are members in some social media, are aware of the possibilities they have and they can easily address any technical problems while avoiding the "dangerous" parts of interaction. The younger the teachers the most technology-oriented they are, so they tend to have a positive stance about social media. Experience helps teachers to realize the usefulness of the use of social media, to test them before their usage and to collaborate with the students, who as digital natives, are well experienced in social media.

This study confirmed other studies which stated Experience as a critical factor of teachers' behavioral intention. For instance this study confirms De Grove's et al. (2012) study about teachers' behavioral intention to use games into classrooms, and Wood's (2010) study for the usage of virtual worlds in colleges.

\section{Perceived Usefulness}

This research revealed that teachers acknowledge how useful the social media are, either they use them or not. They believe that courses that are integrated with social media will be more attractive for the students and they can change the level of their motivation to participate more actively in the classroom and have better learning performance. Although there is always a thought that students will not use social media for learning but for other purposes, e.g. to communicate with their friends or play games, teachers believe that this interaction with social media will improve the communication between students and them and thus the whole educational process. They further argue that it can be established a more personalized communication that gives students the opportunity to ask or say things to their teachers beyond the limitations of the classroom (e.g. some students may feel quite shy to ask in the classroom). In addition they believe that social media may also foster collaborative students' work.

The confirmation of perceived usefulness as a positive factor of the diffusion of an innovation is one of the critical points in Rogers' Theory (2006). In similar 
researches, as Teo's for the usage of technology in schools (2011) and De Grove's for integration of Games in Education (2012), perceived usefulness is a determinant factor and this confirms to this research too.

Trialability

It seems that Greek teachers have a positive attitude in using the social media in their classes if they can test them before the final decision and integration. They feel more confident to respond to any problems that may emerge. They believe that it is better to have a trial period of their usage, in some projects, with several students or in some laboratory courses. It seems that they don't prefer to use some social networks that require 'friendship' with their students (like Facebook), because they believe that this may cause problems in the formal relationship between them and their students.

This study's findings regarding trialability agree with Rogers' Theory (2006) and Kebritchi's study about factors that affect teachers in the usage of computers games in their classes (2010).

\section{Subjective Norms}

The subjective norm, which represents the social pressure that encourages the teachers to use social media in their classes, had no direct effect on their behavioral intention to use them. According to the Theory of Planned Behavior (TPB) it is a critical psychological factor in the adoption of an innovation in education; nevertheless findings revealed that Greek teachers are weakly affected from this factor.

In this research there were some questions regarding the influence of the opinion of school directors, colleagues and students' parents. It was found that the majority of the teachers are not heavily influenced by these opinions and if they decide to use social media in the classroom they will not be affected from such subjective norms. This is similar to Teo's research (2011) about factors influencing teachers' intention to use technology, where one of the results revealed that teachers' intention is somewhat independent from stakeholders' opinion or there is a weak relationship.

Perceived Ease of Use

Greek teachers believe that the usage of social media is quite easy and simple and they think that if they decide to use them in their courses it will not be a difficult project. They also know that the students are already familiar with them. To this end, it was found that perceived ease of use has a weak influence on their intention to use them. This is somehow contradictory to other studies related with Rogers' Theory (2006) and TAM etc. The only problem teachers argued about was that sometimes there is a digital divide between teachers and students and this may cause some difficulties as students are more proficient in using social media than some of their teachers.

Observability

The ability to observe the results of the adoption of an innovative intervention is a critical factor in Rogers' theory (2006). However participants in this study didn't seem to be influenced by this factor towards their decision to use social media. Most of them want to have their own personal view of the use of social media; it seems that they prefer to take a risk and try to introduce them in their courses rather than to observe results from other uses and then make a decision. This is quite similar to the findings of Kebritchi's study (2010) regarding the adoption of computer games in schools.

Curriculum

Greek teachers believe there are not any serious limitations from the formal curriculum in order to adopt social media in schools. Most of them think that 
curriculum is in the right direction towards the use of new technologies and they believe that new educational practices are fostered. On the other hand, many of them tend not to follow strictly the formal curriculum as they try to adapt it to the needs of their classes and their students. They feel quite flexible and most of them are ready to use social media to their classes even when the formal curriculum does not officially provide such directions.

\section{Limitations}

The sample of teachers who took part in the research is relatively small but it was a representative sample, as participants were coming from many geographical areas and covered almost all age groups. In addition, authors believe that the current socioeconomic situation in southern European countries like Greece, has somehow affected the willingness to participate in such a research since most of the teachers are quite frustrated and they don't feel ready to change their way or experiment with new tools and methods or they feel that they have no motives to participate in such initiatives. It is quite probable that in a future time, a new research will employ a larger sample and may provide some better results in terms of the readiness of Greek teachers to innovate. However, authors still believe that the current study contributes to the extant literature, fills the gap of relevant studies in the wider area of southern Europe and provides a solid basis for a fruitful discussion amongst the educational policy stakeholders.

\section{References}

Downes, S. (2005) "E-learning 2.0", eLearn MAGAZINE, available at http://elearnmag.acm.org/featured.cfm?aid=1104968 (accessed November 2012)

De Grove, F., Bourgonjon, J. \& Van Looy, J. (2012), "Digital games in the classroom? A contextual approach to teacher's adoption intention of digital games in formal education", Computers in Human Behavior, vol.28, pp.2023-2033

George, D. R., \& Dellasega, C. (2011), "Use of social media in graduate-level medical humanities education: Two pilot studies from Penn State College of Medicine.”, Med Teach., 33(8), e429-434, doi: 10.3109/0142159X.2011.586749.

Gualtieri, L., Javetski, G., \& Corless, H. (2012), "The integration of social media into courses: A literature review and case study from experiences at Tufts University School of Medicine", Future Learning 1, 79-102, doi:10.7564/12-FULE8

Kale, U. \& Goh, D.(2012), “Teaching style, ICT experience and teachers' attitudes toward teaching with Web 2.0", Educ Inf Technol, Springer Science + Business Media, LLC, doi:10.1007/s10639-012-9210-3

Kebritchi, M. (2010), "Factors affecting teachers' adoption of educational computer games: A case study", British Journal of Educational Technology, vol 41 (no 2) , pp.256-270

Li, J., Wen, Z. (2009), "An Augmented Social Interactive Learning Approach through Web 2.0", 33rd Annual IEEE International Computer Software and Applications Conference, pp.607-611

Motaghian, H., Hassanzadeh, A. \& Moghadam, D.K. (2013). Factors affecting university instructors' adoption of web-based learning systems: Case study of Iran. Computers \& Education vol.61, pp.158-167

Nielsen, S.E. (2010). The Challenges to Diffusion of Educational Computer Games. available at http://www.egenfeldt.eu/papers/ecgbl10-egenfeldt.pdf (accessed November 2012)

Perroti, V. \& Hair, N. (2011). User Experience in Online Social Networks: A Qualitative Analysis of Key Activities and Associated Features. Proceedings of the 44th Hawaii International Conference on System Sciences

Prensky, M. (2001). Digital Natives, Digital Immigrants", From On the Horizon, MCB University Press, Vol.9 No.5.

Rath, L. (2011). The Effects of Twitter in an Online Learning Environment, eLearn Magazine, available at http://elearnmag.acm.org/featured.cfm?aid=1944486 (accessed November 2012)

Rogers, E. M. (1962). Diffusion of Innovations. (1st ed.) New Your, NY: Free Press. 
Rogers, E. M. (2003). Diffusion of Innovations. (5th ed.) New Your, NY: Free Press.

Rosen, D. \& Nelson C.(2008). Web 2.0: A New Generation of Learners and Education, Computers in the Schools, 25:3-4, 211-225

Teo, T. (2011), Factors influencing teachers' intention to use technology: Model Development and test", Computers \& Education vol.57 pp.2432-2440

Wood, L. W. (2010). Faculty Perceptions about Virtual World Technology: Affordances and Barriers to Adoption, Middle-Secondary Education and Instructional Technology Dissertations, Paper 70 